\title{
PERILAKU CARING PERAWAT PELAKSANA RAWAT INAP RUMAH SAKIT DI KABUPATEN INDRAMAYU
}

\author{
Valentina BM Lumbantobing* $\diamond$, F.Sri Susilaningsih*, Maknun Dadi*** \\ *Fakultas Keperawatan Universitas Padjadjaran \\ **Rumah Sakit Umum Daerah Indramayu \\ $\diamond$ Corresponding Outhor: Valentina@unpad.ac.id
}

\begin{abstract}
Perilaku Caring perawat dalam memberikan asuhan keperawatan pada pasien merupakan salah satu elemen sangat berdampak terhadap kualitas asuhan keperawayan. Penelitian ini bertujuan untuk menganalisis persepsi pasien tentang perilaku caring perawat pelaksana di ruang rawat inap rumah sakit. Desain penelitian ini adalah deskriptif kuantitatif dengan purposive sampling didapatkan sebanyak 67 orang pasien yang menjadi responden. Hasil penelitian 37 orang pasien (55.2\%) mempersepsikan perilaku caring perawat masih kurang. Upaya meningkatkan perilaku caring dengan membudayakan perilaku caring terutama aspek afektifnya di lingkungan RSUD Indramayu.
\end{abstract}

Kata Kunci: Perilaku Caring, Perawat Pelaksana

\section{LATAR BELAKANG}

Komponen penting dari sistem perawatan kesehatan rumah sakit adalah untuk peningkatan status kesehatan pasien dan yang berfokus pada penyediaan layanan berkualitas tinggi sesuai dengan kebutuhan pasien. Dengan perkembangan teknologi yang cepat dan meningkatnya persaingan, rumah sakit terus berusaha untuk meningkatkan kualitas layanan (Juhana, Manik, Febrinella, \& Sidharta, 2015). Perawat merupakan tenaga kesehatan dengan jumlah terbanyak di rumah sakit dank arena hal tersebut maka kinerja perawat merupakan salah satu unsur yang berkontribusi sangat penting terhadap kualitas perawatan. Hal ini mendorong manajemen rumah sakit untuk tetap memperhatikan kualitas asuhan yang diberikan pada pasien (Needleman \& Hassmiller, 2009). Asuhan keperawatan yang diberikan secara professional dan tetap memperhatikan indikator mutu rumah sakit antara lain terkait keselamatan dan keamanan pasien akan berdampak pada kepuasan pasien dan meberikan dampak yang positif terhadap status mutu rumah sakit.

Layanan kesehatan yang terjadi dan diberikan di rumah sakit sebagian besar dilakukan oleh perawat, sehingga hal tersebut menjadi perhatian penting untuk menentukan kualitas pelayanan kesehatan di rumah sakit tersebut (Huber, 2011). Hal tersebut juga dikemukakan dalam penelitiannya Dwidiyanti (2007) yang menyatakan bahwa pemberian asuhan keperawatan yang professional mampu mewujudkan kualitas layanan rumah sakit tersebut. Profesionalisme perawat tersebut dapat terbentuk sejak awal memasuku duan pendidikan keperawatan yang didukung dengan pembelajaran akademik dan laboratorium, hubungan interpersonal yang dipupuk dengan baik.

Esensi dalam profesi keperawatan adalah sikap dan perilaku caring. Hal ini mencari penciri dari profesi keperawatan dan menjadi pembeda dengan profesi lainnya. Caring merupakan hal yang utama dalam praktik keperawatan yang senantiasa selalu dilandasi pada nilai kebaikan, perhatian, serta menghormati keyakinan spiritual pasien (Rubenfield, 2007). Caring tidak hanya mempraktikkan seni perawatan, memberi kasih sayang untuk meringankan penderitaan pasien dan keluarga, meningkatkan kesehatan dan martabat tetapi juga memperluas aktualisasi diri perawat (Morrison \& Burnard, 2009). Tokoh keperawatan seperti Watson (2010), Leininger (1988), dan Benner (1989) menempatkan caring sebagai dasar dalam praktik keperawatan.

Data yang ditemukan dari sumber akun media sosial RSUD Indramayu didapatkan adanya masyarakat yang mengeluhkan pelayanannya lambat, perawat yang kurang 
peduli sama pasien, tidak ramah, kasar, dan judes. Ada juga yang mengeluhkan kalau shift malam perawatnya tidur saja dan tidak peduli dengan kondisi pasiennya yang lagi kritis. Bahkan salah satu dari masyarakat ada yang mengatakan petugas minta dihargai dan dihormati itu kalau pelayanannya benar, mereka menyatakan kalau bisa jangan sampai masuk ke rumah sakit itu karena perawatnya kasar dan tidak ramah, serta masih banyak lagi keluhan-keluhan lainnya dari masyarakat mengenai ketidak puasan terhadap pelayanan keperawatan di rumah sakit, dari sekitar 40 orang yang memberikan masukan tersebut semuanya ditujukan ke seluruh petugas rumah sakit termasuk perawat dan 7 orang lainnya langsung ditujukan ke pelayanan keperawatan. Keluhan yang disampaikan tersebut merupakan gambaran nyata atas ketidakpuasan pasien terhadap asuhan yang diberikan oleh perawat. Keluhan pasien terhadap perawat bersumber dari tidak terpenuhinya kebutuhan (bio-psiko-sosialspiritual-kultural). Kondisi ini dapat dihindari dengan memenuhi kebutuhan pasien yang dilandasi perilaku caring, karena implikasi dari perilaku caring adalah kepuasan pasien. Hal ini sesuai dengan hasil penelitian dari Gurusinga, Sulistyaningsih dan Tarigan (2013) yang menyatakan bahwa ada korelasi antara perilaku caring perawat dengan kepuasan pasien rawat inap.

Perilaku merupakan wujud tindakan yang diberikan oleh seseorang terhadap orang lain maupun lingkungan. Perilaku caring merupakan suatu tindakan dengan memperhatikan aspek-aspek perasaan dan situasi orang lain. Keperawatan merupakan profesi yang didasari atas nilai-nilai caring, dan hal ini dapat dipengaruhi oleh faktor individu tersebut baik secara emosi, kematangan psikologis, kemampuan akademik, faktor organisasi dan kegiatan yang diikuti serta faktor religious dan psikologis dari individu tersebut (Gibson, 1997). Hal ini didukung oleh hasil penelitian yang dilakukan oleh Supriatin (2009) di RSUD Kota Bandung, menyatakan bahwa ada hubungan antara faktor usia, masa kerja, kepemimpinan, struktur organisasi dan desain kerja dengan perilaku caring perawat.
Sedangkan menurut penelitian yang dilakukan oleh Setiati (2005), menemukan adanya hubungan antara faktor faktor demografi antara lain status tingkat pendidikan, jumlah besaran penghasilan, status sosial, hubungan dalam keluarga termasuk status marital dengan perilaku caring perawat yang berdampak terhadap tingkat kepuasan pasien.

\section{METODE}

Desain penelitian ini adalah deskriptif Kuantitatif dengan jumlah sampel sebanyak sebanyak 67 orang pasien yang sedang dirawat inap minimal 3 hari perawatan dan sampel diambil dengan menggunakan teknik purposive sampling. Instrumen yang digunakan untuk pengukuran perilaku caring dalam penelitian ini adalah caring Behavior Inventory Questionnaire (CBI). Analisis dilakukan dengan distribusi frekuensi untuk mendapat gambaran perilaku caring perawat pelaksana di ruang rawat inap RSUD Indramayu berdasarkan persepsi pasien.

\section{HASIL}

\section{Analisis Univariat}

Karakteristik responden sebagian besar berusia dewasa menengah sebanyak 36 orang $(53,7 \%)$, berjenis kelamin perempuan sebanyak 41 orang $(61.2 \%)$ dan berpendidikan SD sebanyak 41 orang $(61.2 \%)$.

Tabel 1: Distribusi Perilaku Caring Perawat Pelaksana berdasarkan Persepsi Pasien

\begin{tabular}{lcc}
\hline \multicolumn{1}{c}{ Perilaku Caring } & f & $\%$ \\
\hline Baik & 30 & 44.8 \\
\hline Kurang & 37 & 55,2 \\
\hline
\end{tabular}

Tabel di atas menggambarkan bahwa persepsi pasien tentang perilaku caring perawat pelaksana di ruang rawat inap sebagian besar kurang $(55,2 \%)$. 
Tabel 2: Distribusi Sub Variabel Perilaku Caring Perawat Pelaksana berdasarkan Persepsi Pasien

\begin{tabular}{lcccc}
\hline \multirow{2}{*}{$\begin{array}{l}\text { Sub Variabel Perilaku } \\
\text { Caring }\end{array}$} & \multicolumn{2}{c}{ Baik } & \multicolumn{2}{c}{ Kurang } \\
\cline { 2 - 5 } & f & $\%$ & f & $\%$ \\
\hline $\begin{array}{l}\text { Mengakui keberadaan } \\
\text { Manusia }\end{array}$ & 30 & 44.8 & 37 & 55.2 \\
\hline $\begin{array}{l}\text { Menanggapi dengan } \\
\text { Rasa hormat }\end{array}$ & 31 & 46.3 & 36 & 53.7 \\
\hline $\begin{array}{l}\text { Pengetahuan dan } \\
\begin{array}{l}\text { Keterampilan } \\
\text { profesional }\end{array}\end{array}$ & 29 & 43.3 & 38 & 56.7 \\
\hline $\begin{array}{l}\text { Menciptakan } \\
\text { hubungan Positif }\end{array}$ & 33 & 49.3 & 34 & 50.7 \\
\hline $\begin{array}{l}\text { Perhatian terhadap } \\
\text { yang dialami orang } \\
\text { lain }\end{array}$ & 34 & 50.7 & 33 & 49.3 \\
\hline
\end{tabular}

Berdasarkan tebel di atas dapat diketahui perilaku caring perawat menurut persepsi pasien, sebagian besar yaitu sebanyak 37 orang $(55.2 \%)$ pasien menyatakan perilaku caring yang dilakukan perawat kurang baik. Hal ini juga tercermin pada perilaku mengakui keberadaan manusia yang mayoritas sebanyak 37 orang $(55.2 \%)$ pasien menilai hal tersebut dilaksanakan dengan kurang baik, berkaitan dengan perilaku menanggapi dengan rasa hormat mayoritas sebanyak 36 orang (53.7\%) pasien menilai hal tersebut dilaksanakan dengan kurang baik. Berkaitan dengan pengetahuan dan keterampilan professional sebanyak 38 orang $(56.7 \%)$ pasien menilai kurang baik, berkaitan dengan menciptakan hubungan yang positif sebanyak 34 orang (50.7\%) pasien menilai dilaksanakan dengan kurang baik, namun berkaitan dengan perhatian terhadap yang dialami orang lain sebanyak 34 orang $(50.7 \%)$ pasien menilai hal tersebut dilaksanakan dengan baik.

\section{PEMBAHASAN}

Hasil analisis penelitian menunjukkan sebagian besar perilaku caring perawat pelaksana dipersepsikan kurang baik oleh pasien sebesar (55.2\%). Dengan demikian maka secara keseluruhan lebih dari setengahnya baik menurut pasien menyatakan bahwa perilaku caring yang dilakukan oleh perawat pelaksana masih kurang.

Perilaku caring yang dipersepsikan oleh pasien tersebut kemungkinan besar dilandasi oleh kegiatan perawat yang dianggap sebagai rutinitas dan lebih memprioritaskan pada tindakan delegasi medik dibandingkan dengan asuhan keperawatan dan perilaku caring yang belum dirasakan sebagai hal yang pokok dan dinilai kurang membudaya bagi lingkungan keperawatan. keberhasilan ilmu pengetahuan dan teknologi menyebabkan perawat hanya memberikan perhatian pada tugas-tugas mengobati daripada merawat. Tidak banyak waktu bagi perawat mendengarkan keluhan pasien, memberi dukungan, hal ini disebabkan karena delegasi lebih diberikan untuk tugas-tugas dokter (Tomey, 2006). Pemenuhan kebutuhan biologis menjadi fokus utama perawat, sehingga kebutuhan lainnya seperti kebutuhan psikologis, sosial dan spiritual menjadi kurang diperhatikan. Hasil penelitian ini sejalan dengan yang dikemukakan oleh Supriatin (2009) bahwa sebagian besar perilaku caring masih kurang yaitu $(58,1 \%)$. Pernyataan ini didukung oleh hasil penelitian Zees (2011) menyatakan $(53,3 \%)$ persepsi perawat pelaksana tentang perilaku caring masih kurang.

Kecenderungan hasil perilaku caring perawat yang masih kurang yang dipersepsikan oleh pasien kemungkinan besar dipengaruhi oleh banyak hal, karena persepsi dipengaruhi oleh beberapa faktor antara lain tingkat pengetahuan, sikap, motivasi, kepentingan, minat, pengalaman dan pengharapan, umur, tingkat pendidikan, latar belakang sosial ekonomi, budaya, lingkungan fisik, pekerjaan, kepribadian dan pengalaman hidup individu. Hal ini dapat dilihat bahwa sebagian besar responden berjenis kelamin perempuan dan berpendidikan rendah serta berada pada rentang usia 41-60 tahun, kemungkinan besar adalah sebagian IRT yang jarang terpapar dengan dunia medis dalam pelayanan keperawatan, sehingga keterbatasan pengetahuan terkait peran dan fungsi serta tugas seorang perawat, hal ini mempengaruhi penilaian pasien tersebut terhadap aktifitas 
yang sedang dikerjakan oleh perawat pada saat memberikan asuhan keperawatan.

Hal ini sejalan dengan pendapat Purwaningsih (2018) yang menyatakan bahwa faktur usia merupakan faktor penting dalam menentukan perlaku caring perawat. Dimana perawat yang lebih dewasa memeliki kecenderungan berperilaku caring lebih baik.

Berdasarkan analisis secara dimensi perilaku caring pengetahuan dan keterampilan secara professional dinilai merupakan elemen yang paling rendah dari keempat dimensi lainnya. Pasien mempersepsikan bahwa kualitas pemberian asuhan keperawatan berdasarkan pengetahuan dan kemampuan professional kurang ditunjukkan dengan perilaku-perilaku caring perawat. Hal ini sesuai dengan hasil penelitian yang dilakukan oleh Green Halg, Vanhanen, dan Kyngas (1998 dalam Morisson \& Burnard, 2009) menjelaskan bahwa perawat lebih menunjukkan perilaku caring fisik daripada yang afektif. Pemenuhan kebutuhan biologis menjadi fokus utama perawat, sehingga kebutuhan lainnya seperti kebutuhan psikologis, sosial dan spiritual menjadi kurang diperhatikan. Perilaku caring perawat yang mencerminkan aspek altruisme ini dalam memberikan asuhan keperawatan adalah mengenali karakteristik pasien (umur, pendidikan, pekerjaan, alamat dll), mengenali kelebihan dan kekurangan pasien, mendengarkan apa yang menjadi keluhan dan kebutuhan pasien (Prihandhani, 2014: Malini, 2009).

Caring merupakan esensi dari praktik keperawatan dalam memenuhi kebutuhan manusia. Perawat sebagai caring profession harus memahami secara eksplisit dan implisit tentang apa yang terkandung dalam caring profesional. Watson dengan teori of human care mempertegas bahwa caring sebagai jenis hubungan transaksi yang diperlukan antara pemberi dan penerima asuhan untuk meningkatkan dan melindungi pasien sebagai manusia. Bentuk hubungan perawat dan pasien adalah hubungan yang wajib dipertanggung jawabkan secara profesional (Tomey \& Aligood, 2006). Perilaku caring adalah aktivitas perawat yang penuh dengan keterampilan, suatu proses dan pengambilan keputusan yang berhubungan dengan membantu pasien yang merefleksikan atribut sikap seperti empati, mendukung, belas kasih, melindungi, dan hal-hal lain tergantung kebutuhan, nilai, masalah, nilai dan tujuan yang ingin dicapai oleh individu ataupun kelompok yang dibantu perawat (Leinenger, 1991).

Caring merupakan hal yang menarik yang dikemukakan oleh Pepin (1992 dalam Petterson \& Bredow, 2008), dimana caring tersebut dituangkan dalam dimensi cinta (love) dan pekerjaan (labour). Cinta berupa konsep-konsep afektif seperti altruisme, belas kasih, emosi, keberadaan, hubungan, pemeliharaan dan kenyamanan. Sedangkan caring sebagai pekerjaan berarti peran, fungsi, pengetahuan dan tugas perawat dalam melaksanakan asuhan keperawatan kepada pasien. Pernyataan Pepin tersebut menguatkan bahwa dalam melaksanakan tugas memberikan asuhan keperawatan perawat tidak cukup hanya berdasarkan pengetahuan dan keterampilan yang didapatkan secara akademik, namun juga memperhatikan perilaku manusia yang unit yang membutuhkan perhatian dengan kasih saying dan rasa cinta didalam setiap tindakan pemberian asuhan keperawatan. Seorang perawat diharapkan dapat mengendalikan control perasaan, suasana hati sehingga tetap bisa bekerja secara professional dengan tetap mempertahankan nilai-nilai dasar profesi perawat.

\section{KESIMPULAN}

Perilaku caring perawat pelaksana ruang rawat inap rumah sakit dalam persepsi pasien sebagian besar kurang baik. Menurut pasien aspek yang paling baik telah dilakukan adalah berkaitan dengan perhatian terhadap apa yang dialami orang lain, sedangkan aspek yang paling harus diperhatikan adalah pengetahuan dan keterampilan profesional. Berdasarkan hasil ini manajemen rumah sakit diharapkan dapat mengevaluasi dan menetapkan kebijakan untuk memasukkan perilaku caring perawat dalam standar penilaian kinerja perawat dan standar operasional prosedur pelaksanaan asuhan keperawatan serta memberikan 
reward kepada perawat dengan perilaku caring terbaik, dan memfasilitasi perawat melalui pelatihan-pelatihan terkait yang dapat meningkatkan perilaku caring perawat.

\section{DAFTAR PUSTAKA}

Dwidiyanti, M. (2007). Caring Kunci Sukses Perawat Mengamalkan Ilmu. Hasani: Semarang.

Gibson, J.L. (1997). Organisasi: Perilaku, Struktur, Proses. Binarupa Aksara: Jakarta.

Huber, D. (2011). Leadership and Nursing Care Management. WB Saunders Company: Philadephia.

Juhana, D., Manik, E., Febrinella, C., \& Sidharta, I. (2015). Empirical study on patient satisfaction and patient loyalty on Public Hospital in Bandung, Indonesia. International Journal of Applied Business and Economic Research, 13(6): 4305-4326.

Leininger, M.M. (1988). Care the Essence of Nursing and Health. Wayne State University Press: Detroit.

Malini, H, Sartika, D., Idianola, Edward, Z. (2009). Hubungan kecerdasan spiritual dengan perilaku caring perawat di $R S$ DR. M. Djamil Padang tahun 2009. http://lp.unand.ac.id.

Morrison, P. \& Burnard, P.(2009). Caring and Communicating: Hubungan Interpersonal dalam Keperawatan.. EGC: Jakarta.

Needleman, J., \& Hassmiller, S. (2009). The role of nurses in improving hospital quality and efficiency: Real-world results. Health Affairs. 28(4): 625633.
Prihandhani, S. (2014). Hubungan Faktor Individu dan Budaya Organisasi dengan Perilaku Caring Perawat Pelaksana di Ruang Rawat Inap RSU Ganesha Gianyar. Tesis Program Magister Ilmu Kesehatan Masyarakat Universitas Udayana Denpasar.

Purwaningsih, D.F. (2018). Perilaku Caring Perawat Pelaksana di Ruang Rawat Inap. Jurnal Ilmu Kesehatan. 9(1): 6167.

Rubenfield, M.G., Scheffer, B.K. (2007). Berpikir Kritis dalam Keperawatan. EGC: Jakarta.

Supriatin, E. (2009). Hubungan Faktor Individu dan Organisasi dengan Perilaku Caring Perawat di Ruang Rawat Inap RSUD Kota Bandung. Tesis Program Magister Ilmu Keperawatan FIK UI. Tidak dipublikasikan.

Watson Caring Science Institute. (2010). Core concepts of Jean Watson's theory of human caring/caring science. Retrieved from www.watsoncaringscience.org

Watson, J. (2012). Human caring science: a theory of nursing. Second ed. USA: Jones \& Bartlett Learning, LLC.

Zees, R.F. (2011). Analisa Faktor Budaya Organisasi yang Berhubungan dengan Perilaku Caring Perawat Pelaksana di Ruang Rawat Inap RSUD Prof. Dr. Aloei Saboe Kota Gorontalo. Tesis Program Magister Ilmu Keperawatan FIK UI. 